\title{
壁面からのエコーに関する超音波を利用した 模型実験について
}

\section{1. 緒 言}

エコーはオーディトリアムの音響障害のうち最も有害 なもの〉一つであり、古くからこれを防止するためには、 直接音と $50 \mathrm{msec}$ 以上の時差のある強い反射音が来な いようにすることが強調されて居り、このためには $17 \mathrm{~m}$ 以上の行路差のある反射音が無い上うに設計すべきだと されている。しかし直接音との時間のずれがごく僅かな 反射音は、直接音の補強飞役立つことも古くから知られ ている。またどの程度の時差と強さのものから障害とな るかといろ点について、戦後 Haas 氏によつてスピーチ （独語）の場合のエコーによる percentage disturbance

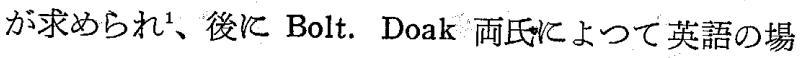
合飞換算されている2。また Muncey, Nickson, Dubout 氏等はスピーチ (英語) と音楽の場合についても研究し て招り゙、未だ日本語に関するデータは無いけれども、 エコーの障害に関する一応の目安怔求められている。

このように、ェコーと聴感との関係は求められていて あ、室の形、壁面仕上等とエコ一発生との関係について の研究は極めて少い、特に屏風折、ポリシリンダ一等の 拡散体を壁面に取付けた場合にどの程度エコ一を少くず ることが出来るかという点については、未だ允分な研究 がないように思われる。

そこで筆者は平面、曲面等の壁面にこれらの拡散体を 取付けた場合に、この壁面からのエコーがどの樣に変化 するかを実験によつて検討することを計画した。まず簡 単のために一つの壁面によつて生じる single echo の多 を対象とし、壁面の形は平面及び凹曲面として、これに 屏風折の凹凸及びポリシリンダ一を取付けた場合につい て検討した。

\section{2. 壁面に拡散体を取付けた場合のエコーに関する理 論的検討}

2.1. 仮定 実際 のオーディトリア ムでエコーが最も 問題となるのは後 壁からのものであ るので、この点を 考光て1図のよう 飞壁面の正面から 音が当る場合につ いてのみ考光、反

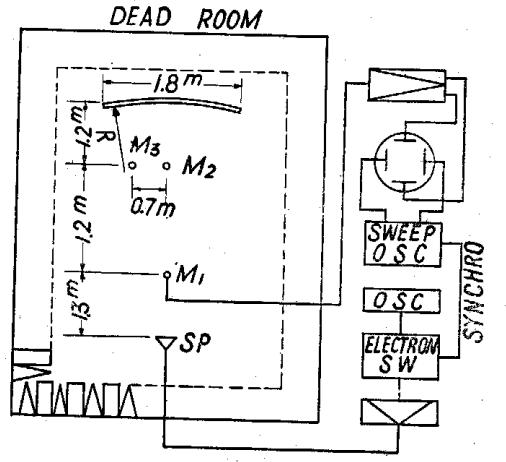

1 図

\footnotetext{
* 東京大学生産技術研究所 第 5 部
}

I. 会員 石 井 聖 光*

射壁、音源、測定点等もこの図のような関係位置とあり。 音源は無指向性で、壁面の周囲からの回折はないとした。 またエコーを考光るのであるから、音を聴取する点で は、音源からの直接音とエコーとなる反射音との間住 の干选は生じないとした。從つて測定点では、直接音と 反射音 (エコー) は完全に分離しているとして取披い、 後述の実験漈しても、この仮定が成立するような短い ACパルスを用いた。

\section{2. 第 1 周波数帯域における考察}

こっで取扱う第 1 周波数帯域とは、壁面に取付けた拡 散体の寸法が、音の波長にくらべて充分小さく、これら の搪散体の效果が認められない周波数带のことである。 そしてこの周波数帯と拡散体の寸法との関係は、この論 文で取扱つているようなエコ一を対象としたものについ ての資料は見当らないが、室内での音の搪散を対象にし

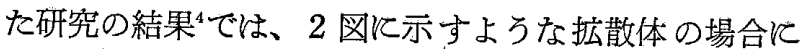
は

$k a \geq 4$ (但 $k=\omega / c, \omega=2 \pi f, c:$ 音速) $b / a \geq 0.15$ となる周波数で拡散効果があることが示されている。従 ১て

$$
f<\frac{2.2 \times 10^{4}}{a}(a: \mathrm{cm} \text { 単位 })
$$

となる周波数帯域がこの節で述べる搪散体が無いに等し い周波数帯となる訳である。

な渒後節で述べるようと筆者のエコ一を対象とした寒 験結果ではこの第 1 周波数帯の上限はるう少し高いよう である。

この周波数帯での直接音と反射音（エコー）との音の 勢力の比は、反射面に抬散体が無いとして考光ればよく、 反射面の基本形が平面の場合は、音のエネルギ一密度が 音源からの距離の 2 乗に反比例するとして求められる。

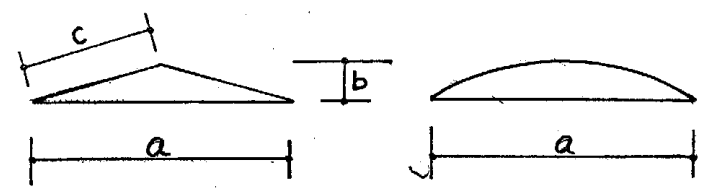

2 図

次に反射面の基本形が一定の曲率半経をもつた曲面の場 合には(1)式のようとなる。（3図参照）

$\frac{E_{R}}{E_{d}}=\left[\frac{d_{1}{ }^{2}}{\left(d_{1}+d_{2}\right)\left(d_{1}+2 d_{2}\right)}\right]\left(\frac{a}{b}\right) \cdots \cdots$

こ $>$ r

$E_{d}:$ 直接音による音響エネルギー密度

$E_{R}:$ 反射音による音響エネルギー密度 
$d_{1}=$ 音源と測定点の

間の距離

$d_{2}=$ 反射面と測定点

の閪の距離

$a:$ 反射壁面の巾

$b:$ 反射壁の両端 $(A$,

B) からの反射音 線が、測定点 $M$

を通り反射壁の両

端を結ぶ線に平行

そ引いた線と交る

点 $C D$ 間の距離

2.3. 第 2 周波数帯に おける考察

こ〉でいろ第 2 周波数

帯とは、搪散体を取付け

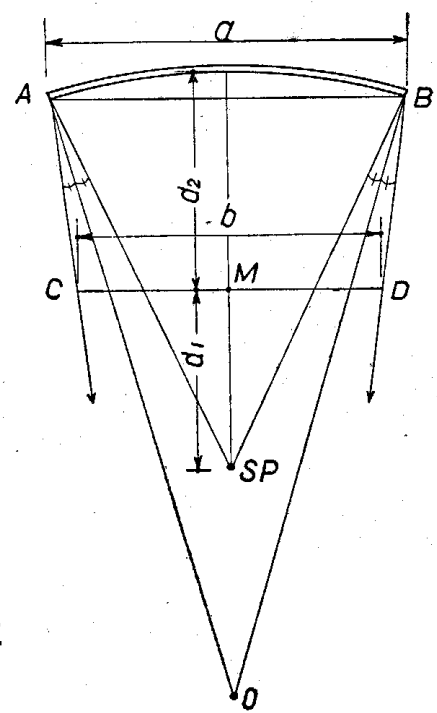

3 図
た壁面が拡散反射をするとみなされる周波数帯のことで ある。この周波数帯の下限は第 1 周波数帯の上限に一致 すると考觉れば求めることが出来る。またこの周波数帯 の上限は、拡散体の巾 $(a)$ とよるばかりでなく、その形

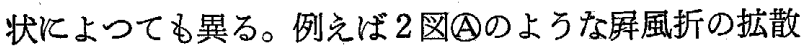
体の場合には、風屏を形成している一つの平面の巾 $c$ が 関係し、これを矩形振動板からの指向性音響輻射等から 類推すれば、

$$
f<\frac{(7 \sim 9) \times 10^{4}}{c}
$$

程度がこの第 2 周波数帯の上限ではないかと考党られ るが、この点は検討を要する。

この周波数帯でのエコ一の強さは、壁面の各部からの 反射音が合成されるため極めて複雑で、その周波数特性 には山谷が出来る。

\section{4. 第 3 周波数帯における考察}

こっでいう第 3 周波数帯とは、拡散体がその形なりに 指向性反射をするとみなされる周波数带のことで、第 2 周波数帯の上限から上は、すべてこの周波数帯に属する わけである。

この周波数帯でのエコーの強さは、個々の指向性反射 面からの反射音の合成によって与兄られるるので一般に は(2)式で示される。

$$
p=\Sigma \frac{A}{r} e^{i(\omega t-r / c)} \cdot R(\alpha, \omega, \theta)
$$

こ小

$p:$ 任意の点のエコーの音圧

$A:$ 音源の強さ

$r$ : 音源から測定点迄の音の通過距離

$\omega=2 \pi f$ $c:$ 音 速

$R(\alpha, \omega, \theta)$ : 拡散体の箘々の面の指向性反射率

\section{3. エコーに関する模型実験について}

この実験を始めるに当つて、模型の縮尺、形状、実験 室、測定用マイクロホン、スピーカーその他の機器につ いて種々検討した結果、次のよう飞定めた。

\section{1. 模型の縮尺について}

なるべく小型の模型で害験することが出来れば、それ だけ模型の取扱い、費用等の面で好都合であるが、実物 と同じ条件を保つためには縮尺したら゙け、実験用の音の 周波数を上げなければならない。このためとは実験に用 いる音が超音波帯に及ぶことになり、このような周波数 帯で用いるマイクロホン、スピーカ一等の機器に関する 色々な問題が生じて来る。この実験では後に述べるょう な空中超音波用のマイクロホン、スピーカーを試作して 用いたのであるが、これらの機器の寸法、 $s / n$ 比等を考 えて縮尺を $1 / 10$ と定めた。

\section{2. 実験室について}

実験室は東大生産技術研究所第 5 部に新設された無響 室を用いた。

\section{3. 测定機器について}

この実験に用いたマイクロホン、スピーカーは共にメ タライズされたポりエステル膜（マイラー）を振動膜と するコンデンサー型のるので、4図、5図のような構造 である。この種のマイクロホン、スピーカーについては 建築音響以外の目的で、すでて若干の研究 $5,6,7,8$ が行わ れている。筆者はこれを参考としてこのエコ一の実験目 的に合うようなるのを設計試作した。即ち直接音とエコ 一とに対する感度差を無くすため、マイクロホンの振動 膜を水平とし、40 kc 迄の音の測定が出来る範囲で、感 度を出来るだけ上げるために、バックプレートの直経を $10 \mathrm{~mm}$ としてある。

このマイクロ ホンとスピーカ 一の総合周波数 特性は 6 図のよ うである。

また $10 \mathrm{kc}$ 以

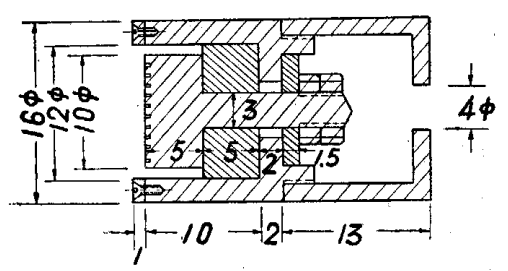

下の周波数では このコンデンサ 一スピーカーの 能率が低下する ので、コーン型 の Tweeter

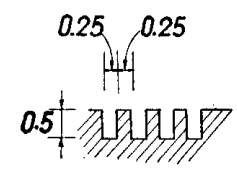

4 図コンデンサーマイクロ ホン UCM-1 の構造図

用いてこの久点を括ぎなつた。

エコ一の観察はブラウン管直視型生研式残響計をシン クロスコープとして用いた。な拓この残響計は可聴周波 用として設計試作したるのであるが、これ手を加えて 周波数帯域を拡張し、50 kc 迄の測定が出来るようにし てある。 

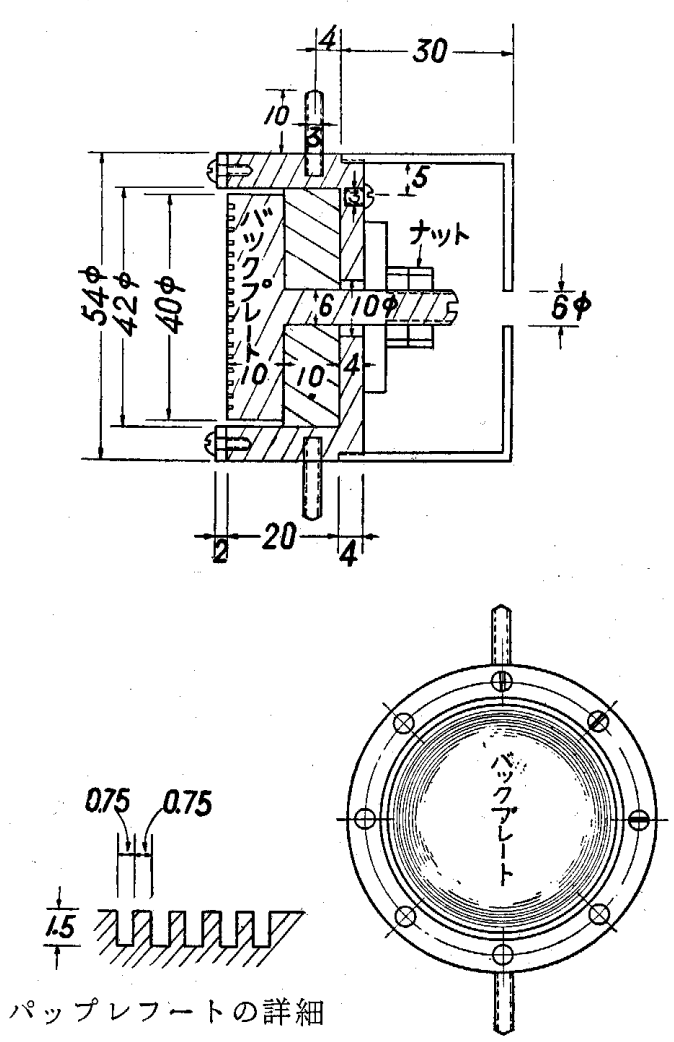

5 図コンデンサースピーカーUCS-1の 構造図

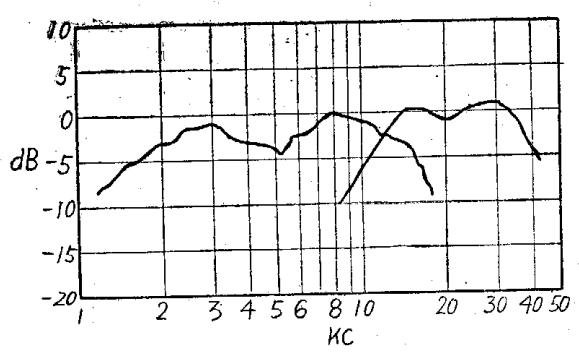

6 図 マイクロホンとスピーカーの総合周波数 特性（左半分は Tweeter 使用のとき）

\section{4. 模型の形状}

この実験用いた壁面の基本形は、币 $1.8 \mathrm{~m}$, 高さ 30 $\mathrm{cm}$ の平面及び凹曲面で、木枠飞黄銅板を張つたるので 曲面の曲率半経は $5 \mathrm{~m}$ と $2.5 \mathrm{~m}$ の 2 種である。これは 実物での半経 $50 \mathrm{~m}$ と $25 \mathrm{~m}$ とあたり、 $50 \mathrm{~m}$ 程度のも のは扇形のオーディトリアムの後壁として、しばしば実 在する程度のものである。

これと取付けた搪散体は、黄銅板でつくり一つの巾が $18 \mathrm{~cm}$ 高さ $30 \mathrm{~cm}$ のもの 10 ケで、中央の出は、攵風 折のものでは $1.8 \mathrm{~cm}$ と $2.7 \mathrm{~cm}$ の 2 種、ポリシリンダ 一は $2.7 \mathrm{~cm}$ のもの1種で、2図のようなものである。

測定の際には、この模型を無響室の床のスノコから約 $1 \mathrm{~m}$ の高さと吊した。

\section{5. 実験の種類}

この実験に抢ける反射壁、スピーカー、マイクロホン 等の関係位置は1図のようである。測定を行つた実験の 種類は、壁面の形 3 種、拡散体 3 種、測定点 3 点で壁面
と拡散体を取付けない場合を含めて種々の組合せのうち 1 表に示す 25 のケースである。

1 表 実験を行つた反射壁の種類（25 種）

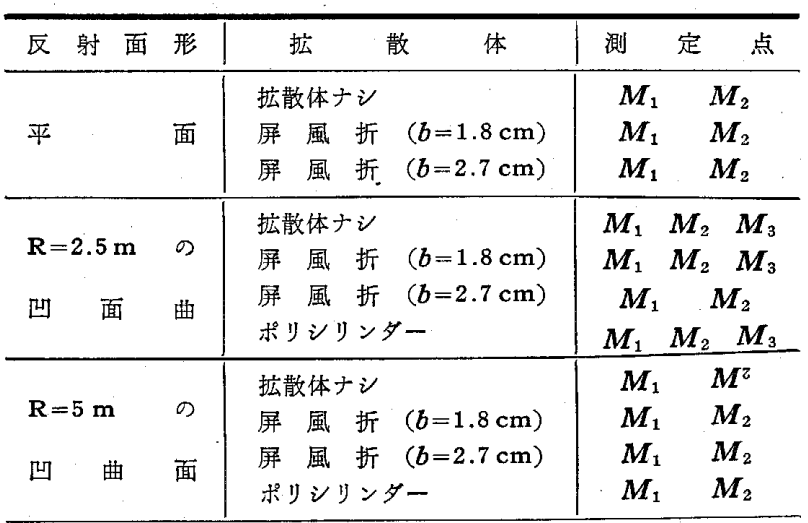

\section{6. 测定方法}

測定法は音源から継続時間 $2 \mathrm{msec} の \mathrm{AC}$ パルスを 出し、この音の直接音が先づマイクロホンに達し、次に 反射面からのエコーが再びマイクロホンに達する状況を ブラウン管に画かせてエコーを測定した。

測定に用いた音の 周波数は実物で $125 \mathrm{c} / \mathrm{s} \sim 4 \mathrm{kc}$ 䒚対 象に考光、1.25 kc $40 \mathrm{kc}$ とした。そしてての測定結果 を直接音を基準とする $\mathrm{dB}$ 尺度でエコ一の強さを示し て、その周波数特性を求めた。

\section{7. 平面壁からのエコーの測定結果}

搪散体を取付けてない平面からのエコ一を測定点 $M_{1}$ 及び $M_{2}$ で測定した結果は 7 図及び 8 図の○印の実線 のようとなり、3 kc 附近から上の周波数ではフラットな 特性で、周波数に関係なく、ほよ゙一定の強さのエコーが 来ることが解る。この周波数帯でのエコ一の強さを音源 からの距離の 2 乗に反比例してエネルギ一がへるとして 計算すると $M_{1}$ 点では $-13.4 \mathrm{~dB}, M_{2}$ 点では $-5.8 \mathrm{~dB}$ で実測値と大変よい一致を示している。

な招 $3 \mathrm{kc}$ 以下で実測値が計算値より小さくなるのは、 反射壁の垂直方向の寸法 $(30 \mathrm{~cm})$ が、音の波長に近くな るため、上下方向に音の拡散が括こるためと思われる。

\section{8. 平面壁に拡散体を取付けた場合のエコーの測定} 結果

前節で述べた平面壁に、群風折の拡散体を取付けた場 合、測定点、 $M_{1}$, 及び $M_{2}$ そ扮けるエコ一は、やはり？ 四及び 8 図の○印と $\Delta$ 印の曲線で示されるようである。

i）測定点 $M_{1}$ 飞括ける結果

$M_{1}$ 点では $2 \mathrm{kc}$ 以下では拡散体を取付けない場合と 大差なく、拡散体の効果が認められない、従つてこの 2 kc 以下が第 1 周波数帯飞属すると考克られる。

$2 \mathrm{kc}$ から $10 \mathrm{kc}$ 附近迄ね 2 種の屏風折のいづれの場 合子周波数特性の $2.1 \sim 2.2 \mathrm{kc}, 5 \sim 5.8 \mathrm{kc}, 7 \sim 8 \mathrm{kc}, 10$ 〜11 kc そ谷があり、谷の間には山が認められる。また 谷となる周波数相互の間には、若干の誤差を認めれば簡 単な整数比が成立つている。 


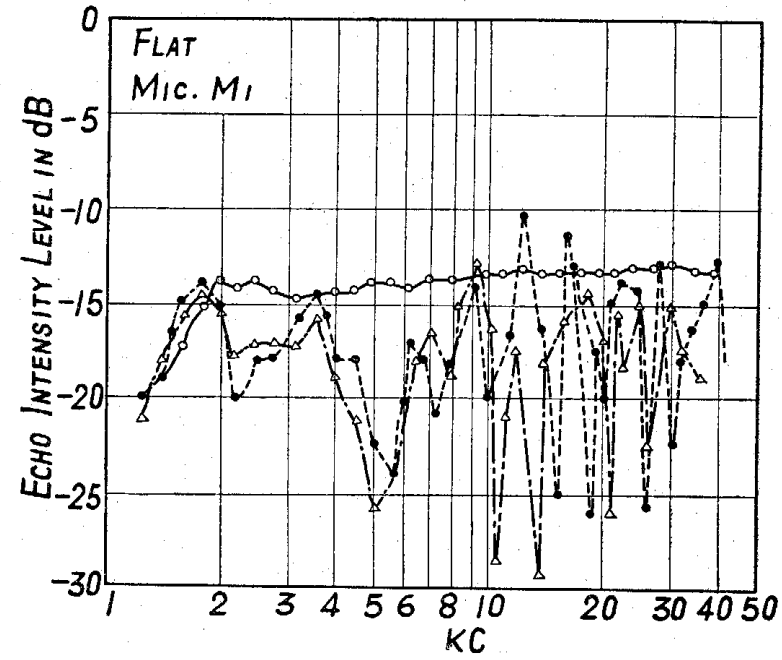

7 図 $M_{1}$ 点炕扮ける平面壁からのエコー ○一○ 拡散体なし

○一 $b=1.8 \mathrm{~cm}$ の屏風折计たとき $\triangle$ 一 $\triangle b=2.7 \mathrm{~cm}$ の屏風折をつけたとき

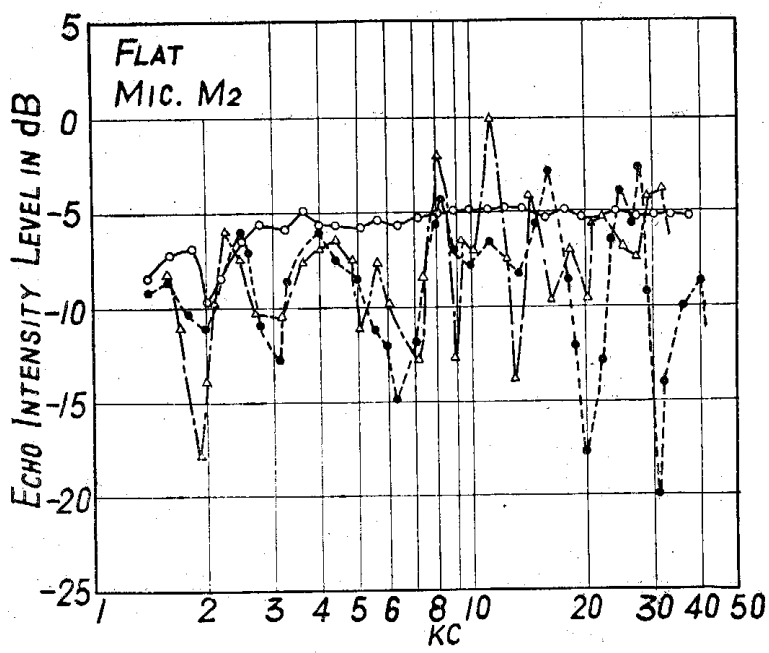

8 図 $M_{2}$ に特ける平面壁からのエコ一

（記号は 7 図と同じ）

これより上の周波数では極めて複雑な形となり、拡散 体によつても周波特性に差が認められる。

次に搪散体の $b=1.8 \mathrm{~cm}$ と $b=2.7 \mathrm{~cm}$ の場合を比較 すると総合的には大きな差は認められず、周波数にも上 るが $b=2.7 \mathrm{~cm}$ の場合の方がエコ一がや小小さいと思 われる程度である。

ii）測定点 $M_{2}$ と拾ける結果

$M_{2}$ 点では $2 \mathrm{kc}$ 以下にも 周波数特性に山凸が認めら れ第 1 周波数帯の範囲が明らかでない。 $2 \mathrm{kc}$ 以上では 3 $\mathrm{kc}$ と $6 \sim 7 \mathrm{kc}$ 附近江谷が、また $4 \mathrm{kc}$ 及び $8 \mathrm{kc}$ 附近 そ山があり、これらの間には一応の整数比が成立つてい る。

$10 \mathrm{kc}$ 附近より上の周波数ではその特性は極めて複雑 である。

\section{9. $R=5 \mathrm{~m}$ の曲面からのエコーの測定結果}

拡散体を取付けてない曲率半経 $5 \mathrm{~m}$ の曲面からのエ コーを測定点 $M_{1}$ 及び $M_{2}$ で測定した結果は 9 図及び
10 図の○印の実線のようで、4 5 kc から上では、周波 数に関係なく一定なエコ一が来る。このエコ一の強さを (1) 式から求めると、 $M_{1}$ 点では $-8.5 \mathrm{~dB}, M_{2}$ 点では一 $4 \mathrm{~dB}$ となり実測值とよく一致している。

$5 \mathrm{kc}$ 以下で次第に低下しているのは、平面の場合と同 様、反射面の縦方向の拡散のためと思われる。

3.10. $R=5 \mathrm{~m}$ の曲面に拡散体を取付けた場合の工 コーの測定結果

前述の曲面に屏風折及びポリシリンダ一の拡散体を取 付けた場合のエコーの強さは、やはり 9 図及び 10 図の

・印、、印及び×印の曲線で示されるようである。

(i) 測定点 $M_{1}$ とけ括る結果

$M_{1}$ 点では挔散体を取付けたことによる効果は $2 \mathrm{kc}$ 以 下ではほとんど認められない。しかし $2 \mathrm{kc}$ 以上では拡 散体を取付けることによつてェコ一は相等小さくなる。 $b=1.8 \mathrm{~cm}$ と $2.7 \mathrm{~cm}$ の屏風折の搪散体を取付けた場

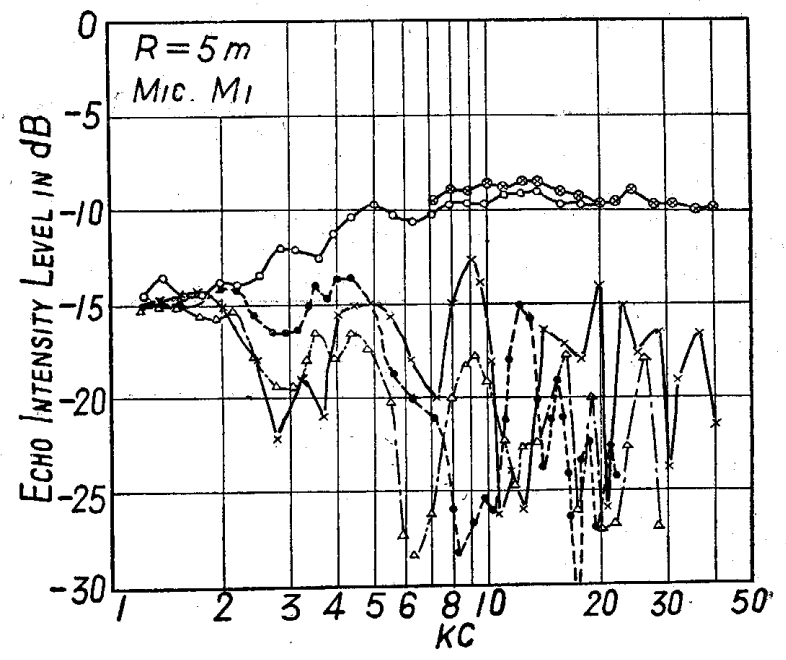

9 図 $M_{1}$ 点汇招汀る $R=5 \mathrm{~m}$ の曲面壁から のエコー

○一○搪散体なし

一一 $b=1.8 \mathrm{~cm}$ の屏風折をつけたとき

$\triangle 一 \triangle b=2.7 \mathrm{~cm}$ の屏風折をつけたとき

メーx ポリンリダーをつけたとき

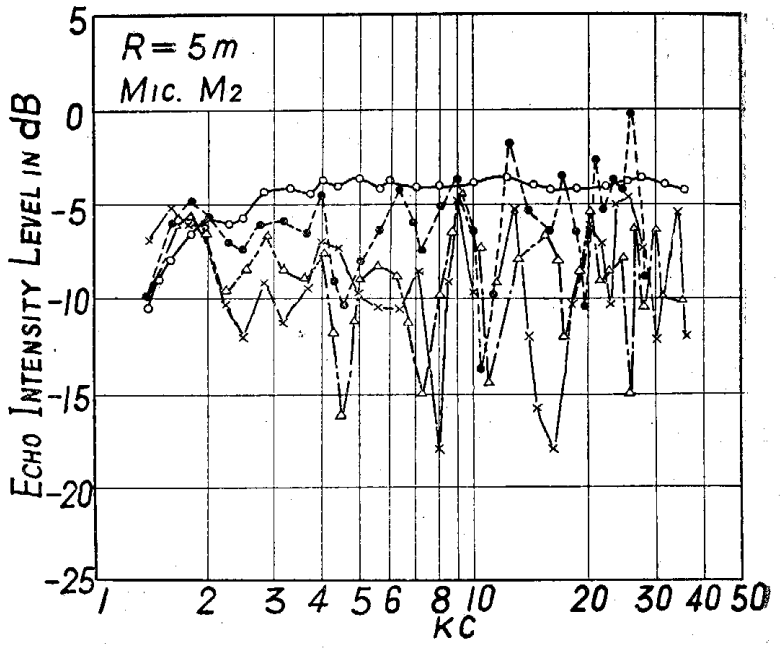

10 図 $M_{2}$ 点注扮ける $R=5 \mathrm{~m}$ 曲面壁からの エコー（記号は 9 図と同じ） 
合を比較すると、 $2.7 \mathrm{~cm}$ の場合の方がす゚つとエコ一が 少く効果は大きい。またエコ一の周波数特性は $b=1.8$ $\mathrm{cm}$ の場合は谷が $3 \mathrm{kc}$ と $8 \mathrm{kc}$ 附近にめり、 $b=2.7 \mathrm{~cm}$ の場合は $3 \mathrm{kc}, 6 \mathrm{kc}, 12 \mathrm{kc}$ 附近飞谷があり、大体の工 コ一の強さは $b=1.8 \mathrm{~cm}$ のとき $-13 \sim-27 \mathrm{~dB} b=2.7$ $\mathrm{cm}$ のとき $-17 \sim-27 \mathrm{~dB}$ である。

ポリシリンダーの場合は $4 \sim 5 \mathrm{kc}$ 附近迄は $b=2.7 \mathrm{~cm}$ の屏風折飞近い特性であるが、これょり上の周波数では エコ一の強さは前述の 2 種類の屏風折のいづれの場合よ りも大きく、 $-13 \sim-26 \mathrm{~dB}$ で、 $-20 \mathrm{~dB}$ 以上のるのが 多く $7 \mathrm{kc}$ 及び 12 14 kc 附近飞谷がある。

$10 \mathrm{kc}$ 附近から上の周波数では、いづれの抎散体をつ けた場合る、エコーの周波数特性は極めて複雑である。 この周波数帯でのエコ一の強さは、 $b=2.7 \mathrm{~cm}$ の屏風折 が最も小さく、ポリシリンダーの場合が最も大きい。こ の理由は後述するように、第 3 周波数帯では反射音が屏 風折の搪散体取付けると左右飞分れ、 $b=2.7 \mathrm{~cm}$ の場 合にはこの傾向が最も強く、正面の $M_{1}$ 点へは反射音が 来にく」なるためである。

ii）測定点 $M_{2}$ 飞怙ける結果

$M_{2}$ 点飞和ける測定結果ではやはり $2 \mathrm{kc}$ 以下では拡 散体の效果が認められず、第 1 周波数帯に属すると考兄 られる。

$2 \mathrm{kc}$ 上上でほ $2.3 \sim 2.5 \mathrm{kc}, 4.5 \mathrm{kc}, 7 \sim 8 \mathrm{kc} 11 \mathrm{kc}$ 附 近に谷があり(ポりシリンダーの場合洱限り $4.5 \mathrm{kc} の$ 谷は認められない）谷と谷との間には山が認められる。 特に $9 \mathrm{kc}$ の山では、いら゙れの拡散体の場合るそのレベ ル迄よく一致している。

$11 \mathrm{kc}$ より上ではいづれの場合も極めて複雑な形とな つている。

エコ一の強さは $b=1.8 \mathrm{~cm}$ の屏風折が最も大きい、 $10 \mathrm{kc}$ 以上飞は拡散体を取付けない場合よりかえつて大 きいェコーの来ることもある。 $b=2.7 \mathrm{~cm}$ の屏風折とポ リシリンダーとを比較すると、周波数特性は異るが、全 体としてのエコ一の強さはそれ程差があるとは思われな い。その大体の值は $b=1.8 \mathrm{~cm}$ の屏風折の場合 0 $11 \mathrm{~dB}$ であり、 $b=2.7 \mathrm{~cm}$ の屏風折とポリシリンダ一は $-5 \sim-17 \mathrm{~dB}$ 程度である。

\section{$3.11 R=2.5 \mathrm{~m}$ の曲面からのエコーの測定結果}

拡散体を取付けてない曲率半経 $2.5 \mathrm{~m}$ の曲面からの エコ一を $M_{1}$ 及び $M_{2}$ 点で測定した結果は、11 図、12 図の○印の曲線のようで、 $5 \mathrm{kc}$ 附近から上の周波数では ほぶ一定のエコーが来る。この強さの計算值は $M_{1}$ 点で は $-5.5 \mathrm{~dB} M_{2}$ 点では $+1 \mathrm{~dB}$ で実測值と $1 \mathrm{~dB}$ 程度 の差で一致している。

$4 \sim 5 \mathrm{kc}$ 以下でのエコ一の強さの低下は反射面の繸方 向の拡散に上るものと思われる。 $M_{1}$ 点に扔けるオシロ グラムは 13 図のようである。

\section{$3.12 R=2.5 \mathrm{~m}$ の曲面に拡散体を取付けた場合のエ コーの測定結果}

この曲面に 2 種の㞔風折及びポリジリンダ一の拡散体 を取付けた場合のエコ一の測定結果はやはり 11 図, 12

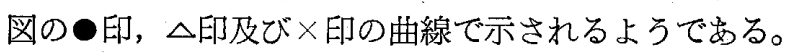

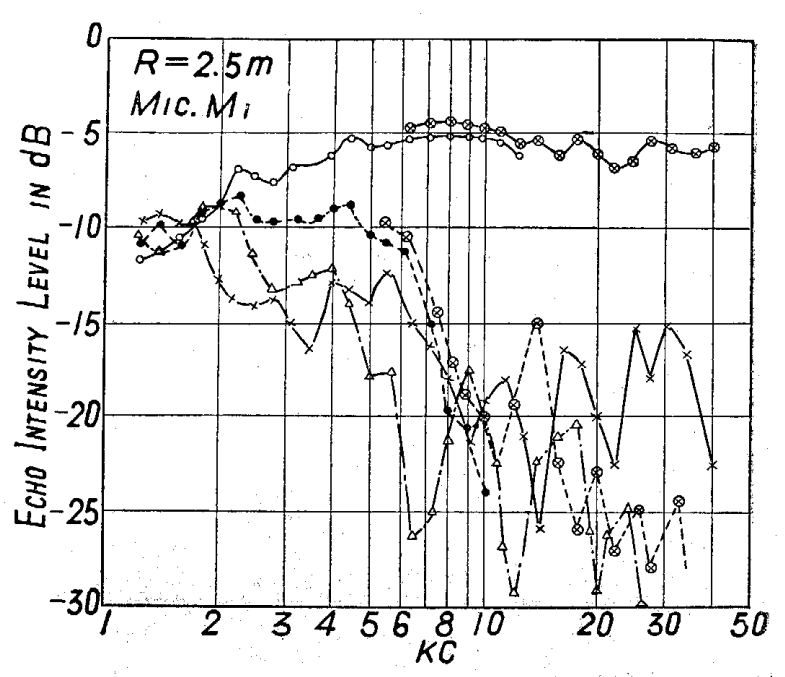

11図 $M_{1}$ 点汇招ける $R=2.5 \mathrm{~m}$ の曲面壁 からのエコー（記号は9.図と同じ）

i）測定点 $M_{1}$ 飞於ける結果

$M_{1}$ 点に招ける測定結果では 2 種の屏風折については $2 \mathrm{kc}$ 以下、ポリシリンダーを取付けた場合は $1.8 \mathrm{kc}$ 以 下ではその効果はほとんど琹められない。従つてこの範 囲が第 1 周波数带飞属すると思われる。

$2 \mathrm{kc}$ 附近から上の周波数では、搪散体を取付けること によつて著しくエコーが減少する。 $2 \mathrm{kc}$ から $10 \mathrm{kc}$ 位迄 の範囲では $b=1.8 \mathrm{~cm}$ の屏風折の場合は周波数と共に エコーが減少し、 $b=2.7 \mathrm{~cm}$ の場合には $6.5 \mathrm{kc}$ 附近に 谷が認められる。この 2 種についてのエコーの大きさ は、後者の方が遙か、小さい。ポリシリンダーを取付け た場合は 2〜3 kc あたりでは他のいら゙れの拡散体より効 果吕大きく、3 10 kc で将 $b=1.8 \mathrm{~cm}$ と $2.7 \mathrm{~cm}$ の屏 風折の中間程度の効果である。

$10 \mathrm{kc}$ 以上ではやほり複雑なるのになるが、エコーの 強さはポリシリンダーの場合が最も大きく $-15 \sim-25$ $\mathrm{dB}$ であり、 $b=18 \mathrm{~cm}$ の屏風折火ついては $14 \mathrm{kc}$ 附近 飞 $-15 \mathrm{~dB}$ の山がある以外は皆 $-20 \mathrm{~dB}$ 以下、また $\mathrm{b}$ $=2.7 \mathrm{~cm}$ の群風折についてはやは $-20 \mathrm{~dB}$ 以下で一 $30 \mathrm{~dB}$ 以下Кなる点も多い。

ii) 測定点 $M_{2}$ 飞和外る結果

$M_{2}$ 点では $M_{1}$ 点の場合之同様に屏風折の場合は $2 \mathrm{kc}$ 以下、ポリシリンダーの場合は $1.8 \mathrm{kc}$ 以下ではその効 果が認められない。

$2 \mathrm{kc}$ 附近から上の周波数では拡散体を取付㐌ると著し くエコーが減少し、10 kc 位迄の範团では $b=1.8 \mathrm{~cm}$ の 屏風折の場合には大きな凹凸がなく周波数と共にェコー が小さくなる。 $b=2.7 \mathrm{~cm}$ の場合には $6.3 \mathrm{kc}$ 附近に大 


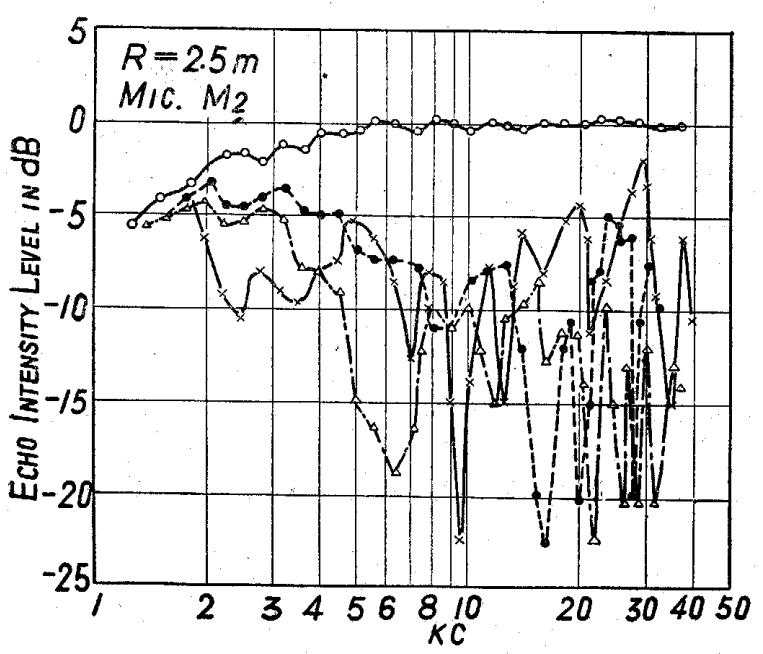

12図 $M_{2}$ 点飞括ける $R=2.5 \mathrm{~m}$ の曲面壁 加らのコー（記号は9図と同じ）

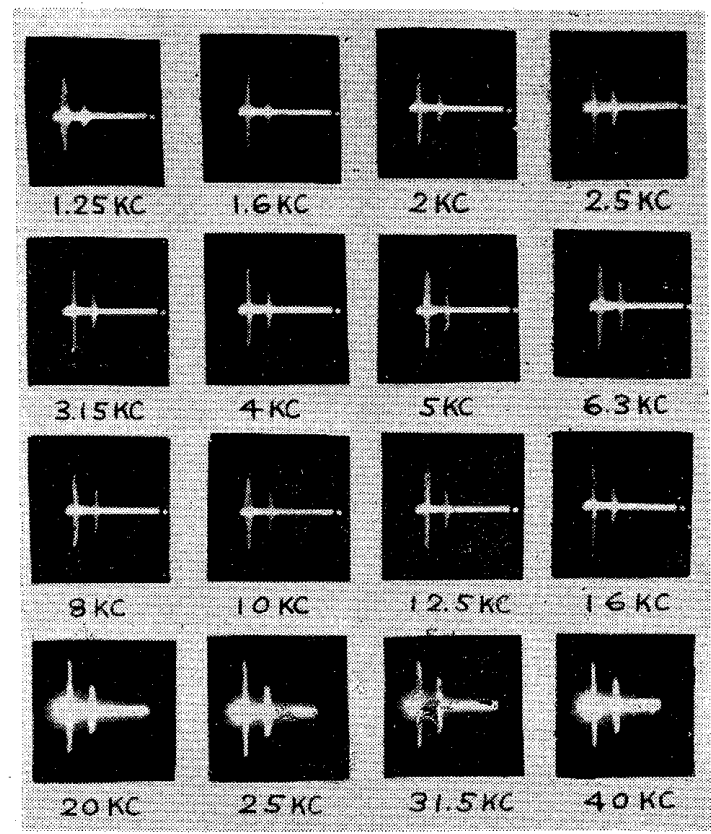

13 図 $R=2.5 \mathrm{~m}$ 拡散体のない場合の $M_{1}$ 点 に抒けるオシログラム

きな谷があり、この両者を比較すると $b=2.7 \mathrm{~cm}$ の場合 の方が遙かにエコ一は小さい。

ポリシリンダーを取付けた場合は、2 2 kc の間は他 のいずれの拡散体の場合よりエコ一は小さく、4 8.5 kc の間では $b=1.8 \mathrm{~cm}$ の姩風折の場合飞大体等しいが $9.5 \mathrm{kc}$ と大きな谷が認められる。

$10 \mathrm{kc}$ 附近から上ではエコ一の周波数特性は極めて複 雑となるが、その強さはポリシリンダ一の場合が最も大 きく、次飞 $b=1.8 \mathrm{~cm}$ 次飞 $b=2.7 \mathrm{~cm}$ の屏風折の順と なる。大体エコーの強さはポリシリンダーが - -3〜 - 15 $\mathrm{dB}, b=1.8 \mathrm{~cm}$ の屏風折のとき $-5 \sim-23 \mathrm{~dB}, b=2.7$ $\mathrm{cm}$ の攵風折のとき $-9 \sim-23 \mathrm{~dB}$ である。このような順 飞なる理由第 3 周波数带では、屏風折の搪散体を取付 けると反射音が左右に分れてマイクロホンの位置にあま り来ない為である。

\subsection{3 実験結果に対する総合的検討}

以上の実験結果から壁面の基本形とこれに取付ける挔 散体の形、寸法等によって、この壁面からのエコ一の発 生が如何に変化するかといろ一般的な事柄を求め、色々 な現象の起る原因に客観的な説明を加兄ようと試みた。

(i) 第 1 周波数帯について

搪散体がその效果を現わさない周波数範囲は、今回実 験を行つた 16 の case うち 15 迄は約 $2 \mathrm{kc}$ 以下である。 従つて 1 つの例外を除けば、拡散体が効果を現さない第 1 周波数帯は(3)式のようになる。

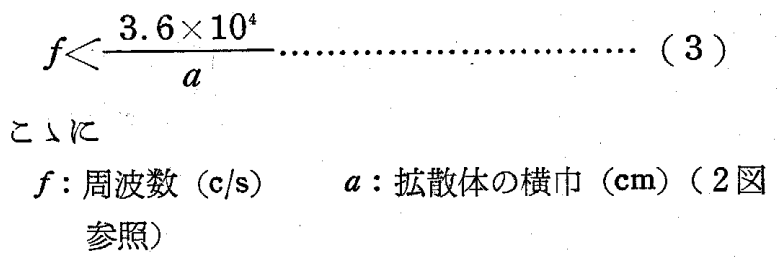

この值は 2 章で述べた室内の残響音の拡散に関する式

$$
f<\frac{2.2 \times 10^{4}}{a}
$$

と比較すると約 5 割程度異つている。この理由は残響 音は拡散体何回る当るのに反して、この実験でのエコ 一は桩散体に一回だけ当つた音であるので、それだけ severe なるのが要求される為と考兄られる。

な拓平面の壁面炋散体を取付けた場合の $M_{2}$ 点で は、第 1 、第 2 周波数帯の境が明確でなかつたがこの原 团は目下検討中である。

(ii) 第 2 周波数帯について

搪散体に上つて、その面に当つた音が拡散反射をする とみなされる周波数範囲はこの実験の結果からは大体 2 $\mathrm{kc}$ から 8 10 kc 程度と考光られる。この理由は、前述 の上万に第 1 、第 2 周波数帯の境は可成りはつきりと求 められているので一応問題はないが、上限の $8 \sim 10 \mathrm{kc}$ は、このあたりでは、第 $2 、$ 第 3 両周波数帯の性質を両 方共持つているのでその境を定めることは容易でない。

しかし 8 図, 12 図等を比較して、 $R$ の小さい場合の 方がかえつてエコーが小さくなる周波数が $8 \mathrm{kc}$ 附近か らであること、15 図で直接音と同等以上のエコーが来 るのが $8 \mathrm{kc}$ 附近から.上の周波数であること等から考兄 て、この附近の周波数から上では第 3 周波数帯としての 性質が強く出て来ると云兄る。

また拡散体を取付けてない反射壁で、エコ一の強さが 計算値（反射壁が整反射すると考兄た場合の）と一致す るのは、前述のように 3 $5 \mathrm{kc}$ 加ら上周波数についあ で゙つて、反射壁の繸の寸法が $30 \mathrm{~cm}$ であることから、 これを屏風折の一つの平面（市 $9 \mathrm{~cm}$ ) の場合飞換算す ると、壁面が完全飞第 3 周波数帯の性質を現すのは10 $15 \mathrm{kc}$ から上となる。

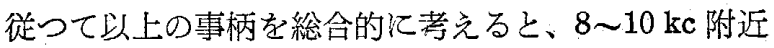
を第 2 、第 3 周波数帯の一応の境とすることが妥当と考 
2 表 平面壁についてのエコーの状況

\begin{tabular}{|c|c|c|c|c|}
\hline 拡 散 体 & 㵋定 & 第 1 周波数带 & 第 2 周波数带 & 第 3 周波数带 \\
\hline \multirow{2}{*}{$\begin{array}{l}\text { 掂散体 } \\
\text { なし }\end{array}$} & $M_{1}$ & \multicolumn{3}{|c|}{ 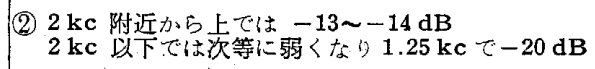 } \\
\hline & $M_{2}$ & \multicolumn{3}{|c|}{ (2) $\begin{array}{l}3 \mathrm{kc} \text { 附近から上では約 }-5 \mathrm{~dB} \\
3 \mathrm{kc} \text { 以下にはは若干の凸かる }\end{array}$} \\
\hline \multirow{2}{*}{$\begin{array}{l}d=1.8 \mathrm{~cm} \\
\text { ○屏風折 }\end{array}$} & $M_{1}$ & $\mid \begin{array}{l}\text { (1) } 2 \mathrm{kc} \text { 以下 } \\
(2)-15 \sim-20 \mathrm{~dB}\end{array}$ & 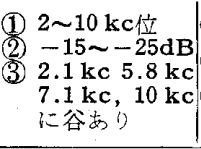 & $\begin{array}{l}1 \text { 1) } 10 \mathrm{kc} \text { 以上 } \\
(2)-12 \sim-25 \mathrm{~dB} \\
(3) \text { 極めて複雑 }\end{array}$ \\
\hline & $M_{2}$ & 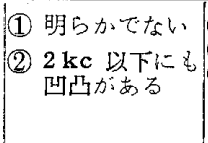 & $\begin{array}{l}\text { (1) } 10 \mathrm{kc} \text { 位迄 } \\
\text { (2) }-6 \sim-5 \mathrm{~dB} \\
\text { (3) } 2 \mathrm{kc}, 3 \mathrm{kc}, \\
6.3 \mathrm{kc} \text { に谷お } \\
3\end{array}$ & $\begin{array}{l}\text { (1) } 10 \mathrm{kc} \text { 以上 } \\
\text { (2) }-3 \sim-20 \mathrm{~dB} \\
\text { (3) 極めて袙雑 }\end{array}$ \\
\hline$d=2.7 \mathrm{~cm}$ & $M_{1}$ & $\left|\begin{array}{ll}(1) & 2 \mathrm{kc} \text { 以下 } \\
(2) & -15 \sim-20 \mathrm{~dB} \\
\text { (3) } & \text { なたららか }\end{array}\right|$ & (2) $\begin{array}{l}2 \sim 10 \mathrm{kc} \\
-15 \sim-26 \mathrm{~dB} \\
2.1 \mathrm{kc}, 5 \mathrm{kc}, \\
8 \mathrm{kc} 10.5 \mathrm{kc} \\
\text { に谷如 }\end{array}$ & $\begin{array}{l}\text { (1) } 10 \mathrm{kc} \text { 以上 } \\
\text { (2) }-14 \sim-30 \mathrm{~dB} \\
\text { (3) 極好て複雑 }\end{array}$ \\
\hline の拼風折 & $M_{2}$ & $\left|\begin{array}{c}\text { (1) 明らかでない } \\
\text { (2) } 2 \mathrm{kc} \text { 以下にも } \\
\text { 凹凸がある }\end{array}\right|$ & $\begin{array}{l}\text { (1) } 10 \mathrm{kc} \text { 位䢓 } \\
\text { (2) }-3 \sim-13 \mathrm{~dB} \\
\text { (3) } 1.9 \mathrm{kc}, 3 \mathrm{kc}, \\
5 \mathrm{kc}, 7 \mathrm{kc}, \\
9 \mathrm{kc} \text { 谷当 }\end{array}$ & 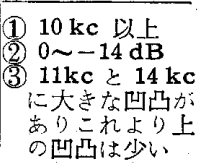 \\
\hline
\end{tabular}

(1)：周波数範囲 第 2 , 第 3 周波数带の境は本文に述べたように複雜 な問題があるので この表の值は大略のもので㐫る

(2)： 直接音の強さ老基潮にしたエコーの強さの大略の值

(3)：エコーの周波数特性

3 表 $R=5 \mathrm{~m}$ の曲面についてのエコーの状況

\begin{tabular}{|c|c|c|c|c|}
\hline 拡 散 体 & 測定点 & 第 1 周波数带 & 第 2 周波数带 & 第 3 周波数带 \\
\hline \multirow{2}{*}{$\begin{array}{l}\text { 搪散体 } \\
\text { なし }\end{array}$} & $M_{1}$ & \multicolumn{3}{|c|}{$\begin{array}{l}\text { (1) 区別なっ } \\
\text { (2) } 5 \mathrm{kc} \text { 附近から上では }-8 \sim 10 \mathrm{~dB} \\
5 \mathrm{kc} \text { 以下では次第に小さくなり } 1.25 \mathrm{kc} \text { で }-10 \\
\mathrm{~dB}\end{array}$} \\
\hline & $M_{2}$ & \multicolumn{3}{|c|}{$\begin{array}{l}\text { (2) } 3 \mathrm{kc} \text { 附近から上では -3〜 -4 dB } \\
3 \mathrm{kc} \text { 以下では次第に小心くなる } 1.25 \mathrm{kc} て ゙-15 \\
\mathrm{~dB}\end{array}$} \\
\hline \multirow[t]{2}{*}{$\begin{array}{l}d=1.8 \mathrm{~cm} \\
\text { の屏風折 }\end{array}$} & $M_{1}$ & $\mid \begin{array}{ll}(1) & 2 \mathrm{kc} \text { 以下 } \\
(2) & -14 \sim-15 \mathrm{~dB} \\
(3) & \text { なだらか。 }\end{array}$ & 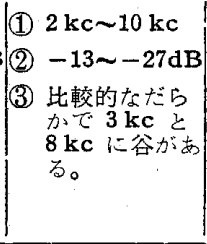 & 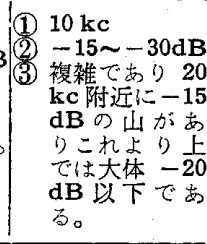 \\
\hline & $M_{2}$ & 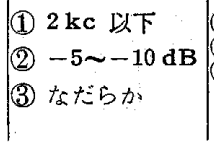 & $\mid \begin{array}{c}\text { (1) } 2 \mathrm{kc} \sim 10 \mathrm{kc} \\
-4 \sim-11 \mathrm{~dB} \\
(3) 2.5 \mathrm{kc}, 4.5 \mathrm{kc} \\
7.1 \mathrm{kc}, 10.5 \mathrm{kc} \\
\text { に谷がある }\end{array}$ & $\mid \begin{array}{ll}(1) & 10 \text { 以上 } \\
(2) & 0 \sim-10 \mathrm{~dB} \\
(\text { () } & \text { 複雑である。 }\end{array}$ \\
\hline \multirow[t]{2}{*}{$d=2.7 \mathrm{~cm}$} & $M_{1}$ & $\left|\begin{array}{ll}(1) & 2 \mathrm{kc} \text { 以下 } \\
(2) & -14 \sim-15 \mathrm{~dB} \\
(3) & \text { なだらか }\end{array}\right|$ & $\left|\begin{array}{l}\text { (1) } 2 \mathrm{kc} \sim 10 \mathrm{kc} \\
-17 \sim-27 \mathrm{~dB} \\
2 \mathrm{kc} \text { そ } 6 \mathrm{kc} \\
\text { に谷がある }\end{array}\right|$ & $\mid \begin{array}{l}\text { (1) } 10 \mathrm{kc} \text { 以上 } \\
\text { (2) -17〜-30dB } \\
\text { (3) 複雜である。 }\end{array}$ \\
\hline & $M_{2}$ & $\left|\begin{array}{ll}(1) & 2 \mathrm{kc} \text { 以下 } \\
\text { (2) } & -5 \sim-10 \mathrm{~dB} \\
\text { (3) } & \text { なだらか }\end{array}\right|$ & $\mid \begin{array}{c}1(1) \\
2 \mathrm{kc} \sim 10 \mathrm{kc} \\
-7 \sim-17 \mathrm{~dB} \\
2.2 \mathrm{kc}, 4.5 \mathrm{kc} \\
7.1 \mathrm{kc} k \text { 谷が } \\
\text { むる。 }\end{array}$ & $\begin{array}{l}\text { (1) } 10 \mathrm{kc} \text { 以上 } \\
\text { (2) }-7 \sim-15 \mathrm{~dB} \\
\text { (3) 複雑で岕る。 }\end{array}$ \\
\hline ポりシリ & $M_{1}$ & $\mid \begin{array}{l}\text { (1) } 2 \mathrm{kc} \text { 以下 } \\
(2)-14 \sim-15 \mathrm{~dB} \\
\text { (3) なだらか。 }\end{array}$ & $\begin{array}{l}\text { (1) } 2 \mathrm{kc} \sim 8 \mathrm{kc} \\
-13 \sim-20 \mathrm{~dB} \\
2.8 \mathrm{kc} 7.2 \mathrm{kc} \\
\text { (3) } \\
\text { 1. 谷がある。 }\end{array}$ & $\begin{array}{l}\text { (1) } 8 \mathrm{kc} \text { 以上 } \\
\text { (2) -13〜-27dB } \\
\text { (3) 複雑である。 }\end{array}$ \\
\hline & $M_{2}$ & $\left|\begin{array}{ll}(1) & 2 \mathrm{kc} \text { 以下 } \\
(2) & -5 \sim-10 \mathrm{~dB} \\
(3) & \text { なだらか }\end{array}\right|$ & $\left|\begin{array}{c}\text { (1) } 2 \mathrm{kc} \sim 10 \mathrm{kc} \\
-5 \sim-17 \mathrm{~dB} \\
8 \mathrm{kc} に 大 き な \\
\text { 谷がある。 }\end{array}\right|$ & $\left\{\begin{array}{l}\text { (1) } 10 \mathrm{kc} 以 上 \\
(2)-5 \sim-17 \mathrm{~dB} \\
\text { (3) 複雑である。 }\end{array}\right.$ \\
\hline
\end{tabular}

4 表 $R=2.5 \mathrm{~m}$ の曲面壁についてのエコー の状況

\begin{tabular}{|c|c|c|c|c|}
\hline 抎散 体 & |測定点| & 第 1 周波数带 & 第 2 周波数带 & 第 3 周波数带 \\
\hline \multirow{2}{*}{$\begin{array}{l}\text { 拡散体 } \\
\text { な.し }\end{array}$} & $M_{1}$ & \multicolumn{3}{|c|}{ 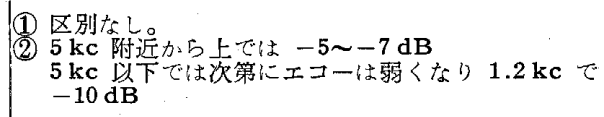 } \\
\hline & $M_{2}$ & \multicolumn{3}{|c|}{$\begin{array}{l}\text { (1) 风别なと } \\
\text { (2) 附近か上では } 0 \mathrm{~dB} \text { 程廃 } \\
5 \mathrm{kc} \text { 以下で次第にエコーは弱くなり } 1.25 \mathrm{kc} \text { で } \\
-6 \mathrm{~dB}\end{array}$} \\
\hline \multirow[t]{2}{*}{$\begin{array}{l}d=1.8 \mathrm{~cm} \\
\text { の屏風折 }\end{array}$} & $M_{1}$ & $\begin{array}{l}\text { (1) } 2 \mathrm{kc} \text { 以下 } \\
\text { (2) -8〜11 dB } \\
\text { (3) なだらか。 }\end{array}$ & $\mid \begin{array}{l}\text { (1) } 2 \mathrm{kc} \sim 10 \mathrm{kc} \text { 附 } \\
\quad \text { 近 } \\
\text { (2) }-9 \sim-20 \mathrm{~dB} \\
\text { (3) なだらか。 }\end{array}$ & 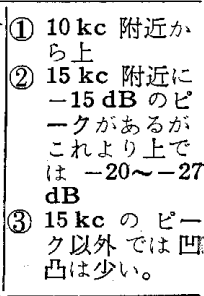 \\
\hline & $M_{2}$ & $\begin{array}{l}\text { (1) } 2 \mathrm{kc} \text { 以下 } \\
(2)-3 \mathrm{~dB} \sim 6 \mathrm{~dB} \\
\text { (3) な゙らか。 }\end{array}$ & 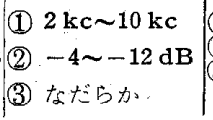 & $\begin{array}{l}(1) 10 \mathrm{kc} \text { 以上 } \\
\text { (2) } \\
\text { (3) 複雑で山谷の } \\
\text { 差がであ。 }\end{array}$ \\
\hline \multirow{2}{*}{$\begin{array}{l}l=2.7 \mathrm{~cm} \\
\text { 屏風折 }\end{array}$} & $M_{1}$ & $\begin{array}{l}\text { (1) } 2 \mathrm{kc} \text { 以下 } \\
\text { (2) }-8 \sim-11 \mathrm{~dB} \\
\text { (3)なたらか }\end{array}$ & 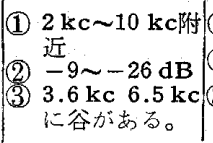 & $\begin{array}{l}\text { (1) } 10 \mathrm{kc} \text { 以上 } \\
(2)-20 \sim-28 \mathrm{~dB} \\
\text { (3) 複 雑 }\end{array}$ \\
\hline & $M_{2}$ & $\begin{array}{l}\text { (1) } 2 \mathrm{kc} \text { 以下 } \\
\text { (2) }-9 \sim-11 \mathrm{~dB} \\
\text { (3) な゙ららか }\end{array}$ & 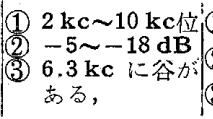 & $\begin{array}{l}1 \text { (1) } 10 \text { 以上 } \\
(2)-9 \sim-23 \mathrm{~dB} \\
\text { (3) 複雑である。 }\end{array}$ \\
\hline \multirow{2}{*}{ ポリシリ } & $M_{1}$ & $\left|\begin{array}{ll}(1) & 1.8 \mathrm{kc} \text { 以下 } \\
(2) & -8 \sim-10 \mathrm{~dB} \\
(3) & \text { な゙らかか }\end{array}\right|$ & $\mid \begin{array}{l}1.8 \mathrm{kc} \sim 10 \mathrm{kc} \\
\text { (2) } \\
\text { (3) } \\
\text { なだらかか }\end{array}$ & 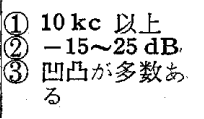 \\
\hline & $M_{2}$ & $\begin{array}{l}\text { (1) } 1.8 \mathrm{kc} \text { 以下 } \\
\text { (2) }-4 \sim-6 \mathrm{~dB} \\
\text { (3)なだらか }\end{array}$ & 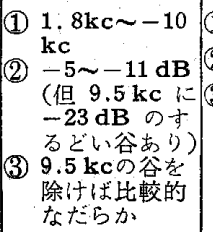 & $\begin{array}{l}\text { (1) } 10 \mathrm{kc} \text { 以上 } \\
\text { (2) }-3 \sim-15 \mathrm{~dB} \\
\text { (3) 複雉な凸凹か } \\
\text { ある。 }\end{array}$ \\
\hline
\end{tabular}

觉られる。そこでこの周波数範囲と拡散体の寸法との関 係を求めると 4 式のようになる。

$$
\frac{3.6 \times 10^{4}}{a}<f<\frac{(7 \sim 8) \times 10^{4}}{c}
$$

こね

\section{$f:$ 第 2 周波数带 $\quad a, c: 2$ 四参照}

iii) 第 3 周波数帯について

拡散体として取付けた屏風折の一つ一つの面が整反射 面とみなされるような第 3 周波数帯ではェコ一は極めて 複雑であるが傾向として次の事柄があげられる。

a. $b=1.8 \mathrm{~cm}$ と $2.7 \mathrm{~cm}$ の屏風では一般に $2.7 \mathrm{~cm}$ の場合の方が数 $\mathrm{dB}$ エコーが小さい。

b. 屏風折の拡散体取付けた場合の $M_{1}, M_{2}$ 点に 括けるエコ一の強さは、壁面の基本形が平面の場合が最 も強く、次がの $R=5 \mathrm{~m}$ 曲面で、最も弱いのが $R=2.5 \mathrm{~m}$ の場合場である。

c. 搪散体がポリシリンダーの場合は、 $R=5 \mathrm{~m}$ の曲 面でも、 $2.5 \mathrm{~m}$ の曲面でもそれ程大きな差は認められな い。 
このうち a.は凹凸のはげしいるのがよく效くことで 当然であるが、b. は $R$ の小さい曲面の方がエコ一が弱 いことで常識坂する。しかしこの原因は 14 図佂示す ように第 3 周波数带では屏風の面に当つた音が整反射し て左右に分れて測定点へ来なくなる為で、 $R=2.5 \mathrm{~m} の$ 曲面の場合がこの傾向が最も大きい。

この事を確かめる目的で 14 図の作図で最るエコ一が 来ると思われる $M_{3}$ 点にマイクロホンを置いて測定した 結果は 15 図のようで、屏 風折の場合飞は非常に大き なエコーが来ることがわか る。またポりシリンダーに すると可成り減少し、 $M_{1}$ 点と $M_{3}$ 点との差が少くな る。これらの点加考克る と、屏風折の搪散体を取付 けると第 3 周波数帯では、 測定位置によつてエコーの 強さにさらがあることが解 り、この点ではポリシリン ダ一の方がすぐれている。

\section{4. 結 論}

以上の実験及びその検討 結果から、壁面に拡散体を 取付けることの効果につい て、次のような事が結論さ

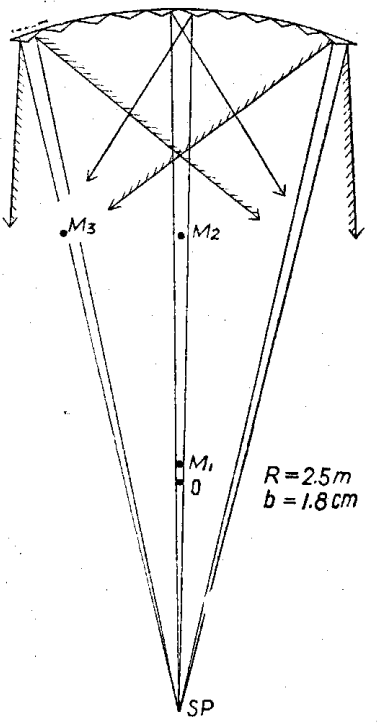

14 図壁曲面屏風折 をつけると反射音 が左右に分れる

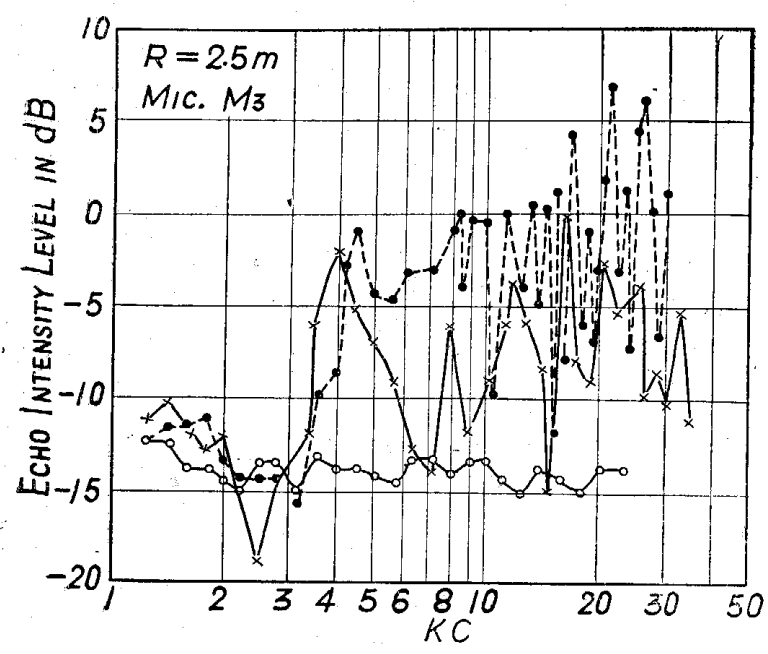

15 図 $M_{3}$ 点での測定結果 （記号は 9 図と同じ）

れる。

(i) 3 式で示される周波数以下では拡散体の効果は認 められない。（この周波数範囲を第 1 周波数帯と呼ぶ）

(ii) 大略 4 式で示される周波数範团では、拡散体を取 付けた壁面は拡散反射をすると考光られる。(この周波 数範囲を第 2 周波数帯と呼ぶ)

(!ii) 第 2 周波数帯の上限より上の周波数では、拡散体
はその形なりと整反射をすると考光られる。(この周波 数範团を第 3 周波数帯と呼ぶ)

(iv) 第 2、第 3 周波数帯では、拡散体を取付けると、 エコーは一般に相当減少する。

（v）拡散体を取付けること飞よつて、エコ一を減少さ せる效果は、壁面の基本形がエコ一を生じやすい凹曲面 である程大きい。

（vi）屏風折の拡散体を取付けると、第 3 周波数带で反 射音が左右に分れるため、測定位置によつてエコ一の強 さが異り、位置によるムラが出来る。

（vii）ポリシリンダーは、（vi）でのベたような不都 合梳少い。

以上の点を総合して、実際のオーディトリアムの後壁 等にエコーを防止する、目的で搪散体を取付ける場合に は、 $100 \mathrm{c} / \mathrm{s}$ 位から上の周波数でエコーを防止しょうと 考光るならば、 3 式から $a>3.6 \mathrm{~m}$ また $b$ は $a / b \geq 0.15$ として $b \geq 54 \mathrm{~cm}$ となる。すなわち拡散体の横巾が 3.6 $\mathrm{m}$ 以上、中央の出が $54 \mathrm{~cm}$ 以上必要である。

次に拡散体の形状は、屏風折よりるポリシリンダーの 方が高音部で座席位置によるェコ一の大きさにムラがな くてよい結果が得られる。

またさらに理想的なるのにするためには 16 図のよう に拡散体の表面にさらに小型の拡散体を取付けて高音の 拡散をさせるとよく、また拡散体を吸音材料でつくるこ ともよいと思われる。小型の拡散体として小型のリブを 取付けることも一つの方法であろう。
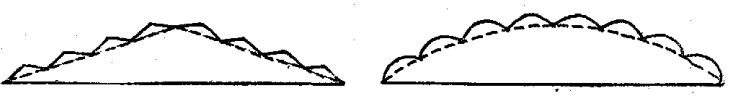

16 図、搪散体の表面にさら飞小型の搪散体を 取付けると高音迄よく搪散するようになる。

\section{5. 結 語}

以上がこの研究の大要である。今後る更にこの問題の 研究を続け、室内音響全般に涉る模型実験になで進及た いと考えている。

最後に終始御指導を頂いた渡辺要先生に深く感謝致し ます。

[参考文献]

1. Haas. Acustica Vol.1, p.49 1951

2. Bolt, Doak. J.A.S.A. Vol. 22, No. 4, July, 1950

3. Muncey, Nickson, Dubout. Acustica Vol. 3, No.3, p 168

4. 例えば二村他 音響学会講演論文集 昭 32.5

5. Kuhl, Schodder, Schröder Acustica Vol. 4, No.5, 1954 p.519

6.7.8. 松沢喜一郎, 音響学会講演論文集 昭 31.11 昭 32.5 昭 32.11 